\title{
Willingness to donate genomic and other medical data: results from Germany
}

\author{
Torsten H. Voigt $\mathbb{D}^{1} \cdot$ Verena Holtz $^{1} \cdot$ Emilia Niemiec $^{2} \cdot$ Heidi C. Howard ${ }^{2} \cdot$ Anna Middleton $^{3,4} \cdot$ Barbara Prainsack $^{5,6}$
}

Received: 8 October 2019 / Revised: 17 February 2020 / Accepted: 25 February 2020 / Published online: 1 April 2020

(c) The Author(s) 2020. This article is published with open access

\begin{abstract}
This paper reports findings from Germany-based participants in the "Your DNA, Your Say" study, a collaborative effort among researchers in more than 20 countries across the world to explore public attitudes, values and opinions towards willingness to donate genomic and other personal data for use by others. Based on a representative sample of German residents $(n=1506)$ who completed the German-language version of the survey, we found that views of genetic exceptionalism were less prevalent in the German-language arm of the study than in the English-language arm (43\% versus $52 \%)$. Also, people's willingness to make their data available for research was lower in the German than in the Englishlanguage samples of the study (56\% versus 67\%). In the German sample, those who were more familiar with genetics, and those holding views of genetic exceptionalism were more likely to be willing to donate data than others. We explain these findings with reference to the important role that the "right of informational self-determination" plays in German public discourse. Rather than being a particularly strict interpretation of privacy in the sense of a right to be left alone, the German understanding of informational self-determination bestows on each citizen the responsibility to carefully consider how their personal data should be used to protect important rights and to serve the public good.
\end{abstract}

\section{Introduction}

Biomedical research and practice are becoming increasingly data driven. Reasons for this lie both in the demand and in the supply side. On the demand side, the idea that medicine and healthcare should be "personalised" in the sense that prevention, diagnosis, and treatment should be tailored to the individual characteristics of people, means that more

Torsten H. Voigt

thvoigt@soziologie.rwth-aachen.de

1 Institute of Sociology, RWTH Aachen University, Aachen, Germany

2 Centre for Research Ethics and Bioethics, Uppsala University, Uppsala, Sweden

3 Society and Ethics Research, Connecting Science, Wellcome Genome Campus, Cambridge, UK

4 Faculty of Education, University of Cambridge, Cambridge, UK

5 Department of Political Science, University of Vienna, Vienna, Austria

6 Department of Global Health \& Social Medicine, King's College London, London, UK data from people are needed. This includes both genomic and other molecular data, biophysical data, and most recently also increasing volumes of behavioural data that is seen to characterise people's "lifestyle". On the supply side, ever wider aspects of people's bodies and lives are "datafied"- that is, they are captured in digital data, via portable or wearable sensors [1]. This means that increasingly large and varied data sets are available that could, in principle, be utilised for medical practice and research.

The mere availability of these data, of course, does not guarantee its quality or utility. Recent scholarship has emphasised the labour and resources needed to make data discoverable, intelligible, and interoperable [2, 3]. Scholars have also warned that "big data won't cure us" [4]. The fact, however, that these data are available creates pressure to use them to improve individual and/or public health [5].

Besides the urgency to improve the interoperability, interpretation, and utility of this data, this development raises manifold questions as to how to share and govern the use of these data, and for whose benefit. There is a wide agreement among scholars that regulation of genomic and medical data sharing should be informed, in some way, by how people would like their data and information to be 
used. Producing such empirical evidence on people's views and preferences is the purpose of the "Your DNA, Your Say" (YDYS) study, a collaborative large-scale survey that is currently available in 14 languages. First results from the English-language survey have been published [6, 7]. Respondents to the English-language arm were based in four countries: the United Kingdom, the United States, Canada, and Australia.

In this article, we report findings from respondents to the German-language version of the survey who resided in Germany at the time of their participation. The Germanlanguage branch of the study is led by the first and last author of this paper (THV and BP). Germany is an interesting case in terms of public attitudes towards medical and genetic innovations and the willingness to donate and share medical and genomic data. In the past, it had been shown that the German public tends to be rather sceptical towards genetic testing [8-10]. More recently though, studies found that Germans are open to the broad use of medical data and data sharing [11-13]. In light of these ambivalent findings, it is important to learn more about peoples' willingness to donate medical and genomic data, to share it with doctors and allow for it to be used for research by non-profit and for-profit organisations.

\section{Methods}

\section{Survey development}

The survey was developed by the Participant Values Task Team (PVTT) from the Global Alliance for Genomics and Health, an international group of researchers (both nonprofit and for-profit), policy makers, clinicians, and patient representatives, all with expertise in scientific, legal or social aspects of clinical, and/or research genomics. Survey items were primarily designed by Anna Middleton, Heidi Howard, and Emilia Niemiec, with input from the PVTT (for details see Ref. [14]).

The first and senior author on this paper, who are both fully fluent in English and German, translated the English survey into German. They did this by initially translating the survey from English to German independently and then comparing the translations and discussing all instances where there were discrepancies between the two translations. The German text was subsequently back translated to English by these authors and a number of volunteers to identify further possible ambiguities and inconsistencies, upon which further adjustments were made. About a dozen bilingual colleagues - some of whom were familiar with the YDYS project while others were not-read and commented on various drafts of the translation before it was finalised.

\section{Sample}

Using a market research company, Dynata ${ }^{1}$, we collected completed surveys from a representative sample of individuals in Germany $(n=1506)$. Dynata adheres to the ESOMAR market research code of conduct and is able to recruit participants from nationally representative research panels from across the world. Participants were paid a small financial reward $(<€ 1)$ for participating. In total, 4391 participants started the survey with 1506 completing it, which is a completion rate of $34.3 \%$. Dynata did not provide information on how many people they invited to take the survey. Where sections of the population were underrepresented, Dynata contacted additional respondents to more closely approximate population data. All participants whose data were analysed for this paper filled in the survey between 19 August and 3 September 2017.

\section{Measures}

Our online survey consists of 29 questions, all of which have multiple choice answers and some of these also have an additional request to elaborate in free text. Questions and answers are the same as the English-language version. Data from $\log$ files show that it took respondents an average of $35 \mathrm{~min}$ to complete the survey. The full survey can be accessed at www.YourDNAYourSay.org. Detailed information on the survey, including the survey design, the short videos that precede different sets of questions and explain basic concepts of genomics and data sharing in nontechnical terms, the methodology as well as data storage, protection and privacy and a discussion of some limitations of the survey can be found in a separate article $[14,15]$.

\section{Statistical analysis}

Sample characteristics were analysed using standard descriptive statistics. Multivariate correlation analyses were used to study effects between different variables, most notably to investigate the association between the willingness to donate DNA for research by different entities and: (1) the personal perception of the status of genetic information (genetic exceptionalism); (2) familiarity with genetics; (3) perspective on harms associated with linking DNA to other personal information. Age, gender, marital status, having children, education level, and religiosity were included as covariates.

We only ran statistical analyses for the German sample, which this paper focuses on. In case of comparison with the English language sample, we used the statistical results

\footnotetext{
${ }^{1}$ At the time when the survey was conducted the same company operated under the brand name ResearchNow (https://www.dynata.com)
} 
published in the respective articles and provide references to those data sets and statistics.

\section{Results}

\section{Sample description}

Regarding age, gender, and education, the distribution in the sample $(n=1506)$ resembles the general population in Germany according to the 2011 census (Table 1). For historical reasons, race or ethnicity is not included in the German census. In our sample, $93 \%$ of participants identified as white. Because of the low absolute numbers $(n=56)$ of respondents who identified as non-whites in our sample, we did not use race or ethnicity as a variable for the analysis.

\section{Genetic exceptionalist views and familiarity with genetics}

Less than half of our respondents held views of genetic exceptionalism ( $43 \%)$. Genetic exceptionalism refers to the idea that genetic material and genetic information are considered as categorically different from other types of information and as such may require additional and/or

Table 1 Sample characteristics by perspective on seeing DNA information as the same/unsure or different to medical information ('genetic exceptionalist' views) ( $N$ indicates count; $\%$ indicates percentage).

\begin{tabular}{|c|c|c|c|c|c|c|c|c|c|c|}
\hline \multirow[t]{2}{*}{ Variable } & \multirow[t]{2}{*}{ Categories } & \multicolumn{2}{|c|}{$\begin{array}{l}\text { Total } \\
(n=1506)\end{array}$} & \multicolumn{2}{|c|}{$\begin{array}{l}\text { Willing } \\
(n=844)\end{array}$} & \multicolumn{2}{|c|}{$\begin{array}{l}\text { Unwilling } \\
(n=257)\end{array}$} & \multicolumn{2}{|c|}{$\begin{array}{l}\text { Unsure } \\
(n=405)\end{array}$} & \multirow[t]{2}{*}{$p$} \\
\hline & & $N$ & $\%$ & $N$ & $\%$ & $N$ & $\%$ & $N$ & $\%$ & \\
\hline \multirow{2}{*}{$\begin{array}{l}\text { Genetic } \\
\text { exceptionalist views }\end{array}$} & No & 865 & 57.44 & 438 & 50.64 & 164 & 18.96 & 263 & 30.40 & \multirow[t]{2}{*}{$<0.0001$} \\
\hline & Yes & 641 & 42.56 & 406 & 63.34 & 93 & 14.51 & 142 & 22.15 & \\
\hline \multirow[t]{3}{*}{ Genetic knowledge } & Unfamiliar & 1066 & 70.78 & 533 & 50.00 & 195 & 18.29 & 338 & 31.71 & \multirow[t]{3}{*}{$<0.0001$} \\
\hline & Familiar & 439 & 29.15 & 310 & 70.62 & 62 & 14.12 & 67 & 15.26 & \\
\hline & Missing & 1 & 0.07 & 1 & 100 & 0 & 0 & 0 & 0 & \\
\hline \multirow[t]{6}{*}{ Age } & 30 and under & 379 & 25.17 & 250 & 65.96 & 48 & 12.66 & 81 & 21.37 & \multirow[t]{6}{*}{$<0.0001$} \\
\hline & $31-40$ & 239 & 15.87 & 129 & 53.97 & 38 & 15.90 & 72 & 30.13 & \\
\hline & $41-50$ & 282 & 18.73 & 137 & 48.58 & 51 & 18.09 & 94 & 33.33 & \\
\hline & $51-60$ & 264 & 17.53 & 148 & 56.06 & 43 & 16.29 & 73 & 27.65 & \\
\hline & Over 60 & 342 & 22.71 & 180 & 52.63 & 77 & 22.51 & 85 & 24.85 & \\
\hline & Missing & 0 & 0 & 0 & 0 & 0 & 0 & 0 & 0 & \\
\hline \multirow[t]{4}{*}{ Gender } & Female & 764 & 50.73 & 417 & 54.58 & 126 & 16.49 & 221 & 28.93 & \multirow[t]{4}{*}{0.052} \\
\hline & Male & 731 & 48.54 & 423 & 57.87 & 126 & 17.24 & 182 & 24.90 & \\
\hline & Prefer not to say & 11 & 0.73 & 4 & 36.36 & 5 & 45.45 & 2 & 18.18 & \\
\hline & Missing & 0 & 0 & 0 & 0 & 0 & 0 & 0 & 0 & \\
\hline \multirow[t]{4}{*}{ Children } & No & 704 & 46.75 & 400 & 56.82 & 123 & 17.47 & 181 & 25.71 & \multirow[t]{4}{*}{0.090} \\
\hline & Yes & 781 & 51.86 & 438 & 56.08 & 127 & 16.26 & 216 & 27.66 & \\
\hline & Prefer not to say & 21 & 1.39 & 6 & 28.57 & 7 & 33.33 & 8 & 38.10 & \\
\hline & Missing & 0 & 0 & 0 & 0 & 0 & 0 & 0 & 0 & \\
\hline \multirow[t]{4}{*}{ Education } & Tertiary & 462 & 30.68 & 284 & 61.47 & 82 & 17.75 & 96 & 20.78 & \multirow[t]{4}{*}{0.002} \\
\hline & Secondary & 820 & 54.45 & 451 & 55.00 & 128 & 15.61 & 241 & 29.39 & \\
\hline & Primary or less & 224 & 14.87 & 109 & 48.66 & 47 & 20.98 & 68 & 30.36 & \\
\hline & Missing & 0 & 0 & 0 & 0 & 0 & 0 & 0 & 0 & \\
\hline \multirow[t]{3}{*}{ Religiosity } & $\begin{array}{l}\text { Not a } \\
\text { religious person }\end{array}$ & 967 & 64.21 & 526 & 54.40 & 182 & 18.82 & 259 & 26.78 & \multirow[t]{3}{*}{0.045} \\
\hline & A religious person & 538 & 35.72 & 318 & 59.11 & 75 & 13.94 & 145 & 26.95 & \\
\hline & Missing & 1 & 0.07 & 0 & 0 & 0 & 0 & 1 & 100 & \\
\hline \multirow[t]{3}{*}{ Relationship } & $\begin{array}{l}\text { Married/civil } \\
\text { partnership/living } \\
\text { together }\end{array}$ & 869 & 57.71 & 485 & 55.81 & 155 & 17.84 & 228 & 26.35 & \multirow[t]{3}{*}{0.186} \\
\hline & $\begin{array}{l}\text { Divorced/single/ } \\
\text { widowed }\end{array}$ & 636 & 42.22 & 359 & 56.45 & 102 & 16.04 & 175 & 27.52 & \\
\hline & Missing & 1 & 0.07 & 0 & 0 & 0 & 0 & 1 & 100 & \\
\hline
\end{tabular}


special governance measures (e.g., specific laws for genetic data). For the purpose of this publication we considered the answer "For me, DNA information is different to other medical information" as indicating a genetic exceptionalism view. In the German language sample, this number is ten percentage points lower than among participants in the English-language survey, where over half (52\%) of YDYS survey participants subscribed to genetic exceptionalism. Participants had the option to give free text answers on their reasons as to why they consider genetic information exceptional. The three most common reasons were that "it is unique", it is "the most personal data we have", and "it clearly only belongs to yourself". In terms of sociodemographic variables, there was very little variation between those who did and did not hold genetic exceptionalist views. Respondents who held genetic exceptionalist views were more likely to be under the age of 30 (this age group made up $29 \%$ of people with genetic exceptionalist views versus $25 \%$ in the overall sample) and more likely to have tertiary education (34\% versus $31 \%$ ).

About a third of our participants stated that they were familiar with DNA, genetics, or genomics. Familiarity with DNA, genetics or genomics refers to more than just knowing about DNA but actual experience: "Yes, I'm familiar through my work, personal interests or family/ medical history". The three most frequently reported sources for familiarity about genetics were personal interest in ancestry and genealogy websites $(33 \%)$, personal or family related experiences due to a genetic condition $(\sim 11 \%)$, and familiarity obtained through professional experience outside of the field of genetics $(\sim 10 \%)$. In contrast to the topic of genetic exceptionalism, where sociodemographic factors did not correlate with specific views, we found that participants who reported previous familiarity with genetics were more likely to: have a university degree $(45.9 \%$ versus $30.7 \%$ in the overall sample), hold views of genetic exceptionalism (52.7\% versus 42.6 ); have no children (50.7\% versus $46.8 \%$ ); be religious (39.8\% versus $35.7 \%$ ) and be under the age of 30 (37.9\% versus $25.2 \%$ ) (Table 2).

\section{Sensitivity towards different types of personal data}

When asked whether all personal data-such as holiday photos, bank information, and medical and DNA information-should have the same level of protection, or whether any data type deserved special protection, $58 \%$ of our respondents said that they should all be treated the same. A much smaller proportion $(34 \%)$ said that these types of information deserve different levels of protection (without yet specifying which types of information deserved more, and which ones less protection), and $8 \%$ of participants were not sure. When those who said that different data types deserved different levels of protection were asked to rank
Table 2 Sample characteristics by being familiar or unfamiliar with genetics ( $N$ indicates count; \% indicates percentage).

\begin{tabular}{|c|c|c|c|c|c|}
\hline \multirow[t]{2}{*}{ Variable } & \multirow[t]{2}{*}{ Category } & \multicolumn{2}{|c|}{ Familiar } & \multicolumn{2}{|c|}{ Unfamiliar } \\
\hline & & $N$ & $\%$ & $N$ & $\%$ \\
\hline \multirow{2}{*}{$\begin{array}{l}\text { Genetic } \\
\text { exceptionalist views }\end{array}$} & Yes & 232 & 52.73 & 409 & 38.37 \\
\hline & No & 208 & 47.27 & 657 & 61.63 \\
\hline \multirow[t]{2}{*}{ Relationship } & $\begin{array}{l}\text { Married/civil } \\
\text { partnership/ } \\
\text { living together }\end{array}$ & 250 & 56.82 & 619 & 58.12 \\
\hline & $\begin{array}{l}\text { Divorced/ } \\
\text { Single/ } \\
\text { Widowed }\end{array}$ & 190 & 43.18 & 446 & 41.88 \\
\hline \multirow[t]{3}{*}{ Willingness to donate } & Yes & 311 & 70.68 & 533 & 50.00 \\
\hline & No & 62 & 14.09 & 195 & 18.29 \\
\hline & Not Sure & 67 & 15.23 & 338 & 31.71 \\
\hline \multirow[t]{3}{*}{ Gender } & Female & 217 & 49.32 & 547 & 51.31 \\
\hline & Male & 216 & 49.09 & 515 & 48.31 \\
\hline & Prefer not to say & 7 & 1.59 & 4 & 0.38 \\
\hline \multirow[t]{3}{*}{ Children } & Yes & 211 & 47.95 & 570 & 53.47 \\
\hline & No & 223 & 50.68 & 481 & 45.12 \\
\hline & Prefer not to say & 6 & 1.36 & 15 & 1.41 \\
\hline \multirow[t]{3}{*}{ Education } & Tertiary & 202 & 45.91 & 260 & 24.39 \\
\hline & Secondary & 207 & 47.05 & 613 & 57.50 \\
\hline & Primary or less & 31 & 7.05 & 193 & 18.11 \\
\hline \multirow[t]{2}{*}{ Ethnicity } & White & 398 & 93.65 & 1009 & 97.49 \\
\hline & Non-White & 27 & 6.35 & 26 & 2.51 \\
\hline \multirow[t]{2}{*}{ Religiosity } & Yes & 175 & 39.77 & 363 & 34.05 \\
\hline & No & 265 & 60.23 & 702 & 65.85 \\
\hline \multirow[t]{3}{*}{ Age } & Under 30 & 167 & 37.96 & 212 & 19.89 \\
\hline & $30-60$ & 197 & 44.77 & 588 & 55.16 \\
\hline & 60 and over & 76 & 17.27 & 266 & 24.95 \\
\hline
\end{tabular}

these data types according to how much protection they deserved, banking information was ranked highest (76\%) with medical and DNA information coming second (both were ranked highest by $67 \%$ of respondents). Holiday photos were considered least sensitive (13\%).

\section{Willingness to donate medical and genetic data}

A bit more than half (56\%) of our respondents were willing to donate medical and DNA information, either to medical doctors or to (non- or for-profit) research. Participants were classified as willing to donate if they said they would agree to make their data available to at least one of the three groups: medical doctors, non-profit researchers, or for-profit researchers. This proportion is lower than in the English speaking countries where more than $67 \%$ were willing to donate their medical and DNA information in at least one scenario [6]. 
When asked whether they would donate their DNA and medical information for use by medical doctors, almost half of our respondents (48\%) said they would; about one quarter $(25 \%)$ said they would not, and $28 \%$ said they were unsure (Table 3). The proportions were roughly similar in response to the question of whether they would donate their DNA and medical information for use by non-profit researchers, with slightly fewer (42\%) giving a straightforwardly positive answer and slightly more saying no (28\%; $29 \%$ said they were unsure). Our respondents were considerably less willing to make their DNA and medical information available to for-profit researchers: less than a quarter $(23 \%)$ were willing to do so, while almost half $(48 \%)$ were not, and $29 \%$ said they were unsure. Those who were unsure whether or not to donate their medical or DNA information made no distinction between the potential user group. Those who were willing to donate clearly distinguished between medical doctors and non-profit research on the one hand, and for-profit research on the other, with a clear preference to donate to the former two.

We investigated the possible influences on people's willingness to donate and we found two main factors. First, there was variation between those who held genetic exceptionalist views and those who did not. Second, previous familiarity with genetics had a moderating effect on willingness to donate. Participants with genetic exceptionalist views were overall slightly more likely to donate DNA and medical data (63\% versus $56 \%$ ). This difference was observed for all three domains with $55 \%$ versus $48 \%$ for medical doctors, $50 \%$ versus $42 \%$ for non-profit, and $28 \%$ versus $23 \%$ for for-profit research. In line with the overall sample, willingness to donate was the lowest for for-profit research. In contrast, participants who did not hold genetic exceptionalist views were significantly less likely to be willing to donate their medical information, with only $19 \%$ willing to donate their DNA and medical information for for-profit research (Table 3).

Similar effects could be observed for participants who considered themselves familiar with genetics. Overall, they were significantly more willing than others to donate DNA and medical information (71\%). Their willingness to donate to medical doctors and for non-profit was also very high at $58 \%$ and $56 \%$, respectively. Most notably, 35\% of participants with previous genetic familiarity were also willing to donate their information to for-profit research. Thus, previous genetic familiarity had an even stronger effect than genetic exceptionalist views on willingness to donate medical information.

\section{Multivariate analysis of attitudes towards donation}

In our multivariable analysis, we used a multinomial logistic regression model to analyse the determinants on willingness to donate. We included the following variables as covariates with possible influencing effects: genetic exceptionalist views, familiarity with genetics, age, gender, having children, education level, and religiosity (Table 4).

Participants who were unwilling or unsure about donating their medical and DNA information were less likely to express genetic exceptionalist views (odds ratio (OR) 0.71; $95 \%$ confidence interval (CI) $0.52-0.96 ; p=0.026$ for unwilling and OR 0.71 ; CI $0.55-0.91$; $p=0.008$ for unsure). In addition, those who were unwilling were less likely to be familiar with genetics (OR 0.63; CI 0.45-0.89; $p=0.01)$. Participants who were unsure about donating their information were also less likely to be familiar with genetics (OR 0.41; CI 0.29-0.56; $p<0.001$ ). We found substantive differences regarding the willingness to donate across reported age groups. Those who were unwilling or unsure about donating had lower odds of being 30 years or younger (OR 0.61; CI $0.40-0.92 ; p=0.020$ for unwilling and OR 0.66; CI 0.47-0.94; $p=0.020$ for unsure) than those who were willing to do so. Furthermore, we found some sociodemographic differences between those who were willing to donate and those who were unwilling. Participants who were unwilling to donate their medical and DNA information showed lower odds in terms of having children (OR 0.71; CI 0.51-0.99; $p=0.043$ ) than those who were willing to do so. Compared with those who were willing to donate, those who were unwilling had also lower odds of being religious (OR 0.73; CI 0.53-1.00; $p=0.051$ ). For those who were unsure about donating we found no significant associations with any sociodemographic data.

In summary, those who were unwilling or unsure about donating their information were significantly less likely to view DNA data and medical data as being different to have gathered genetic familiarity so far and be under the age of 30 than those who were willing to donate. In addition, those unwilling to donate seem to be less likely to have children and to be religious than those who were willing to donate.

\section{Discussion}

Three findings from the German sample are particularly striking and merit further discussion: first, that German participants were on average less willing to make their data available for research than participants in the Englishlanguage survey; second, that within the German sample, those who were more familiar with genetics, and those who held genetic exceptionalist views, were more willing to donate their data; and third, that those who held genetic exceptionalist views tended to be more educated and younger than the rest of the sample. We will now consider each of these groups in turn. 


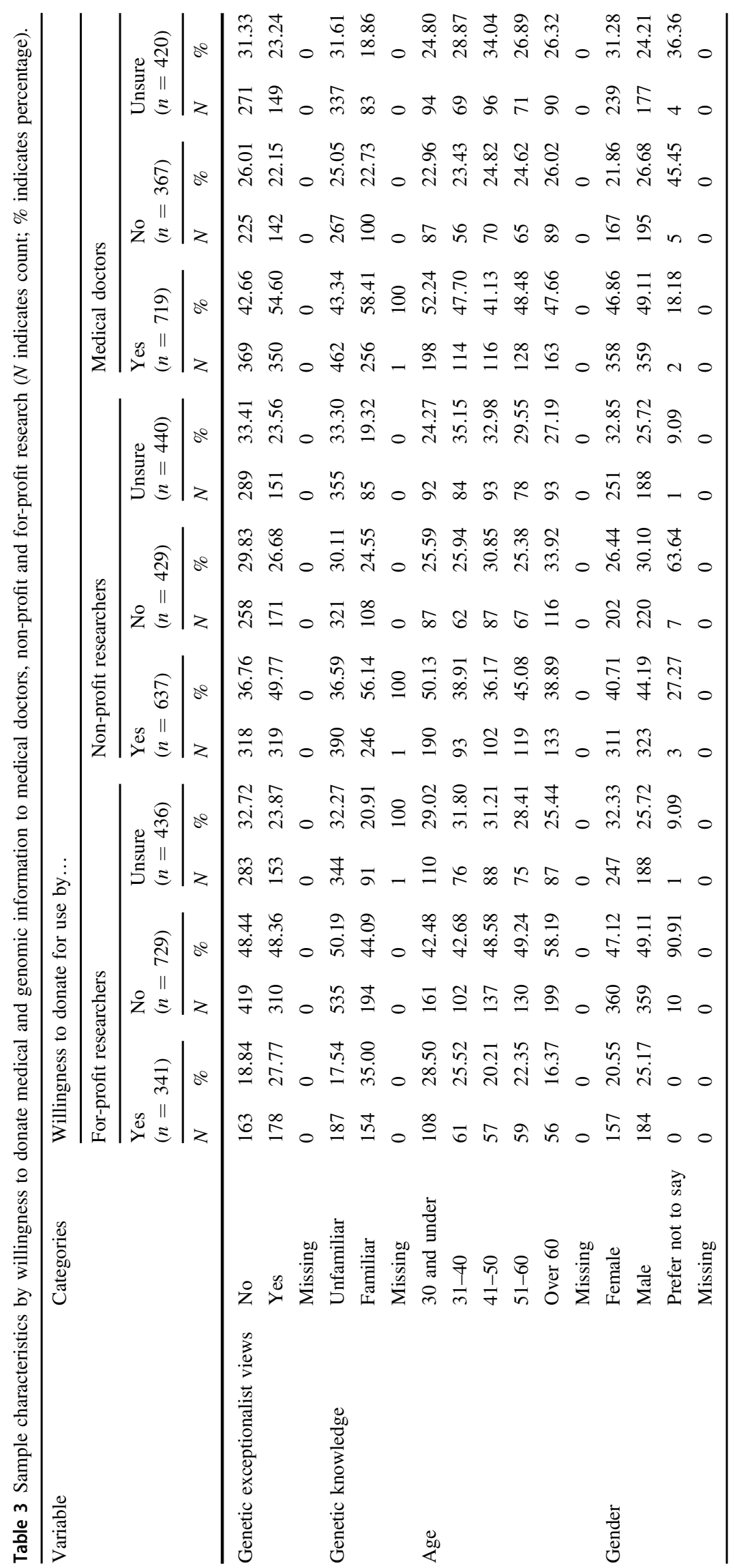


Table 4 Multivariate analysis of attitudes towards donation.

\begin{tabular}{|c|c|c|c|c|c|c|c|c|c|}
\hline \multirow[t]{2}{*}{ Variable } & \multirow[t]{2}{*}{ Category } & \multicolumn{4}{|c|}{ Unwilling } & \multicolumn{4}{|c|}{ Unsure } \\
\hline & & OR & LCI & UCI & $p$ & OR & LCI & UCI & $p$ \\
\hline \multirow[t]{2}{*}{ Genetic exceptionalist views } & No & Ref. & & & & Ref. & & & \\
\hline & Yes & 0.71 & 0.52 & 0.96 & 0.026 & 0.71 & 0.55 & 0.91 & 0.008 \\
\hline \multirow[t]{2}{*}{ Genetic knowledge } & Unfamiliar & Ref. & & & & Ref. & & & \\
\hline & Familiar & 0.634 & 0.45 & 0.89 & 0.010 & 0.41 & 0.29 & 0.56 & 0.000 \\
\hline \multirow[t]{3}{*}{ Age } & 30 years and under & 0.61 & 0.40 & 0.92 & 0.020 & 0.66 & 0.47 & 0.94 & 0.020 \\
\hline & $30-60$ years & Ref. & & & & Ref. & & & \\
\hline & 60 years and older & 1.38 & 0.96 & 1.97 & 0.075 & 0.79 & 0.57 & 1.09 & 0.152 \\
\hline \multirow[t]{2}{*}{ Gender } & Female & Ref. & & & & Ref. & & & \\
\hline & Male & 0.94 & 0.70 & 1.26 & 0.682 & 0.81 & 0.63 & 1.04 & 0.098 \\
\hline \multirow[t]{2}{*}{ Children } & No & Ref. & & & & Ref. & & & \\
\hline & Yes & 0.71 & 0.51 & 0.99 & 0.043 & 0.95 & 0.71 & 1.25 & 0.702 \\
\hline \multirow[t]{2}{*}{ Tertiary education } & No & Ref. & & & & Ref. & & & \\
\hline & Yes & 1.01 & 0.73 & 1.40 & 0.93 & 0.77 & 0.57 & 1.03 & 0.084 \\
\hline \multirow[t]{2}{*}{ Religious } & No & Ref. & & & & Ref. & & & \\
\hline & Yes & 0.73 & 0.53 & 1.00 & 0.051 & 1.02 & 0.78 & 1.32 & 0.894 \\
\hline
\end{tabular}

\section{Lower willingness to donate in the German than in the English-language sample}

As noted, 56\% of the respondents in the German sample were willing to donate medical and DNA information to medical doctors, or to (non- or for-profit) research, compared with over $67 \%$ of respondents to the Englishlanguage survey [6]. The survey data do not give us any insights into the reasons for the lower levels of willingness to make their DNA and medical information available for research. We hypothesise that lower willingness to share data with institutions may be related to the particular prominence of data protection and privacy in public discourses in Germany.

In a 2010 Eurobarometer survey, which included questions about biobanks and data privacy, German respondents articulated the highest level of concern about the protection of their genetic data of all EU countries [10]. The question was included in the Eurobarometer special Report [16]. Since then, one more Eurobarometer, published in 2015, addressed a similar topic, namely data protection [17]. In that survey, German respondents held very sceptical views. Because the survey did not include questions on genetic information specifically, it is not possible to compare attitudes over time.

The high level of concern with regards to sharing medical and genomic information, as well as data privacy may relate to the specific understanding of informational selfdetermination in Germany, which is not only considered a fundamental right of citizens, but it entails the idea that the strict protection of personal data "is essential for a free and self-determined development of the individual [...]. If citizens cannot oversee and control [...] what kind of information about them is openly accessible in their social environment, and if they cannot even appraise the knowledge of possible communication partners, they may be inhibited in making use of their freedom" [18]. Also, the German Genetic Diagnosis Act (Gendiagnostikgesetz, GenDG), which entered into force on 1 February 2010, shows a strong focus on the right to informational selfdetermination. The right to "informational self-determination" is grounded in Art. 2 (1) and Art. 1 (1) of the German Constitution (Grundgesetz), which protect the personal sphere of life, guaranteeing the respect of human dignity, and the right of free development of one's personality. The concept of informational self-determination was introduced by the German Federal Constitutional Court (Bundesverfassungsgericht) in a ruling relating to personal information. In its decision on 15th December 1983 it held that " $[\ldots]$ in the context of modern data processing, the protection of the individual against unlimited collection, storage, use and disclosure of his/her personal data is encompassed by the general personal rights of the Basic Constitutional Law. This basic right warrants in this respect the capacity of the individual to determine in principle the disclosure and use of his/her personal data. Limitations to this informational self-determination are allowed only in case of overriding public interest". The Court held that every citizen has a right to control the flux of all information relating to him or her. It also reasoned that the present and future conditions of data 
processing and collection permit a wide variety of possible abuses against which the individual has to be protected [19].

Interpreted in this light, the greater hesitance of German respondents to make their information available for use by institutions is not necessarily a sign of distrust in institutions, or a lack of willingness to help others. It could also be an expression of people's perceived duty and role as citizens. The latter may also help to explain why there was a clear preference for making their DNA and medical information available to non-profit research in the German sample (see Table 3), which could be seen as a commitment to using one's personal data in such a way that it creates public benefits. This interpretation is in line with findings from a qualitative study on NHS England's care.data programme and the reasons as to why people opt out [20].

\section{Participants holding genetic exceptionalist views, and those who are more familiar with genetics, are more likely to be willing to make their information available}

We also found that participants who held genetic exceptionalist views (63\%), and those familiar with genetics (71\%), were more likely to be willing to make their DNA or medical information available for use by institutions than the average of the German sample (56\%). This is largely in line with findings from the English-language survey, where a very similar, higher proportion of those holding genetic exceptionalist views, and those being familiar with genetics, were more willing to donate their data, with the greatest willingness among those who both held genetic exceptionalist views and were familiar with genetics [7]. In the German sample, previous genetic familiarity had an even stronger effect on people's willingness to donate than genetic exceptionalist views.

Also here, we have no indication from the survey data as to why those who believe that genetic information is special, and those who consider themselves familiar with this topic, are more willing to make their information available than others. Drawing upon the work of colleagues exploring this issue in other studies, we think that the analysis of Hobbs et al. is particularly relevant $[9,10]$. In their work with focus groups in Germany and the United Kingdom, which included biobank participants and members of "general" publics, these authors found that both in the German and British sample, the main reason to participate was the idea that people's data "contributed to the 'common good', typically presented by participants as the progress of medical science or improved population health" [10]. We hypothesise that also in our sample, the more people felt they understood the potential of genetics, and the more they felt that genetic information was "special" in its role to explain health and disease, the more strongly they felt a duty to contribute to health research with public benefits.

Familiarity with DNA, genetics and genomics also increases the willingness to donate medical and genomic information. This finding is in line with other studies such as Balck et al. [9]. While they find that Germans are overall more critical of genetic testing than their comparative sample of Finnish respondents, they also find that education is positively correlated with a more positive attitude towards genetic testing. We think that this is due to the fact that knowing about details of genetics and genomics helps to realistically assess opportunities and risks and increases the willingness to donate personal data.

\section{Genetic exceptionalists were younger and more educated}

The third finding that needs further discussion is that in our sample, respondents who held genetic exceptionalist views were slightly overrepresented under the age of 30 and more likely to have tertiary education ( $34 \%$ versus $31 \%$ ). The latter finding - that tertiary education corresponded positively with the holding of genetic exceptionalist viewswas also present in the larger, English-language sample [7]. A possible explanation for this is that the longer people have been exposed to science education or training, the more they are aware of distinctive features of genetic information, e.g., it is familial and unchangeable. Through this awareness they believe that genetic information is a "special" kind of information, which is different to other personal data. Assuming that many respondents would have been exposed to science education and training during or after the Human Genome Project, where public and also expert discourses focused heavily on the special role and value of genetic and genomic data, this may have contributed to a greater prevalence of genetic exceptionalist views among those who were in education and training for longer.

A correlation that we found in the German sample that was not found in the English-language survey was the association between younger age and genetic exceptionalism. A possible explanation for the correlation of genetic exceptionalism and younger age among Germans could be the current public debate in Germany about the use of genetic information by the police, which is a debate that young people in particular participate in [21]. This could account, in part, for the greater prevalence of genetic exceptionalism in younger people in Germany. It would be necessary to conduct further quantitative and qualitative research in order to substantiate this claim and learn more about the reasons for this correlation. 


\section{Conclusion}

This paper reports from the German arm of the YDYS study, a research collaboration to explore understandings and views of publics in many countries and world regions towards the use of their medical, DNA, and other data. On the basis of a representative sample of the German population, our main findings include that the proportion of those holding exceptionalist views is lower (43\%) than in the English language part of the survey (52\%), and that those holding exceptionalism views are more likely to be young and educated. Also, the proportion of those who are willing to donate their information to research was found to be considerably lower in the German sample (56\%) than in the English-language arm (67\%), with the willingness to donate to for-profit research being lowest. We also found that those willing to donate (regardless of the purpose of the research) tended to be more familiar with genetics, and more likely to hold views of genetic exceptionalism.

We believe that these findings can best be explained with reference to the special status that data protection has in German public discourse. As noted, the right to information self-determination assumes an important role in German law and for the identity of many Germans. It is not to be understood merely as a strong emphasis on privacy in the sense of a right to be let alone [18]. Instead, it imposes a positive responsibility on people to think carefully about how their data should be used, as exercising control over data is part of one's autonomy and ultimately also an expression of citizenship. The expression of autonomy through exercising one's right to informational self-determination is not, in turn, a solipsistic activity where people seek to maximise their own individual gain; on the contrary, they are expected to utilise their data in such a way that it protects their own rights and creates benefits for others or even for the entire collective.

Against the backdrop of the important role that informational self-determination plays in German public discourse it does make sense that the proportion of people holding genetic exceptionalist views are relatively lowbecause there is great awareness of the need to carefully control the use of all data types, not only genetic data. The same perceived responsibility to carefully think about who one makes her personal data available to could explain the relatively low willingness to donate data for research in the German sample. Those with greater familiarity with genetics, however, and those who believe that genetic data are "special", are more aware of the benefits that medical research can obtain with the help of genetic data specifically and thus are more willing to donate it.

Acknowledgements We would like to thank the following people from GA4GH for their encouragement and infrastructure support:
Peter Goodhand, Adrian Thorogood, Erika Kleiderman, Julia Wilson, and Bartha Knoppers. This work was also supported by Global Alliance for Genomics and Health, with their funding delivered via Wellcome (GA4GH grant, with thanks to Audrey Duncansen). We would also like to thank the web team from the Wellcome Sanger Institute who made sure the German translation worked effectively in the survey: James Smith, Claire Steed, and Paul Bevan. We would also like to thank the team who contributed to the concept and delivery of the Your DNA, Your Say project: Erick Scott, Jason Bobe, Richard Milne, Katherine I. Morley, Danya Vears, Jerome Atutornu, and Lauren Farley. We also thank four anonymous reviewers for this journal as well as Ann Morning, Catherine Lee, and Wendy Roth for instructive criticism on an early version of this article. Open Access Funding provided by Projekt DEAL.

Funding This work was supported by Wellcome grant [206194] paid to AM via Society and Ethics Research Group, Connecting Science, Wellcome Genome Campus, and through the personal research fund of BP at King's College London, which covered the costs of data collection from the German sample.

\section{Compliance with ethical standards}

Conflict of interest The authors declare that they have no conflict of interest.

Publisher's note Springer Nature remains neutral with regard to jurisdictional claims in published maps and institutional affiliations.

Open Access This article is licensed under a Creative Commons Attribution 4.0 International License, which permits use, sharing, adaptation, distribution and reproduction in any medium or format, as long as you give appropriate credit to the original author(s) and the source, provide a link to the Creative Commons license, and indicate if changes were made. The images or other third party material in this article are included in the article's Creative Commons license, unless indicated otherwise in a credit line to the material. If material is not included in the article's Creative Commons license and your intended use is not permitted by statutory regulation or exceeds the permitted use, you will need to obtain permission directly from the copyright holder. To view a copy of this license, visit http://creativecommons. org/licenses/by/4.0/.

\section{References}

1. DeFrancesco L, Jarchum I. Focus on wearable sensors. Nat Biotechnol. 2019;4:329.

2. Tempini N, Leonelli S. Genomics and big data in biomedicine. In: Gibbon S, Prainsack P, Hilgartner S, Lamoreaux J, editors. Routledge Handbook of Genomics, Health and Society, 2nd ed. New York, NY: Routledge; 2018. p. 24-31.

3. Fiske A, Buyx A, Prainsack B. Health information counselors: a new profession for the age of big data. Acad Med. 2019;1:37.

4. Neff G. Why big data won't cure us. Big Data. 2013;3:117-23.

5. Weber GM, Mandl KD, Kohane IS. Finding the missing link for big biomedical data. J Am Med Assoc. 2014;24:2479-80.

6. Middleton A, Milne R, Thorogood A, Kleiderman E, Niemiec E, Prainsack B, et al. Attitudes of publics who are unwilling to donate DNA data for research. Eur J Med Genet. 2019;5:316-23.

7. Middleton A, Milne R, Howard H, Niemiec E, Robarts L, Critchley $\mathrm{C}$, et al. Members of the public in the USA, UK, Canada and 
Australia expressing genetic exceptionalism say they are more willing to donate genomic data. Eur Hum J Genet. 2020;28:424-34.

8. Schiermeier Q. Germans mix support and scepticism for genetic engineering. Nature. 1998;393:299.

9. Balck F, Berth H, Meyer W. Genetic testing and molecular biomarkers. Genet Test Mol Biomark. 2009;6:743-50.

10. Hobbs A, Starkbaum J, Gottweis U, Wichmann HE, Gottweis H. The privacy-reciprocity connection in biobanking: comparing German with UK strategies. Public Health Genom. 2012;5:272-84.

11. Richter G, Krawczak M, Lieb W, Wolff L, Schreiber S, Buyx A. Broad consent for health care-embedded biobanking: understanding and reasons to donate in a large patient sample. Genet Med. 2018;20:76-82.

12. Richter G, Borzikowsky C, Lieb W, Schreiber S, Krawczak M, Buyx A. Patient views on research use of clinical data without consent: legal, but also acceptable? Eur J Hum Genet. 2019;27:841-7.

13. Bossert S, Kahrass H, Strech D. The public's awareness of and attitude toward research biobanks-a Regional German Survey. Front Genet. 2019;9:190.

14. Middleton A. Society and personal genome data. Hum Mol Genet. 2018;27:R8-R13.
15. Middleton A, Niemiec E, Prainsack B, Bobe J, Farley L, Steed C, et al. "Your DNA, Your Say": global survey gathering attitudes toward genomics: design, delivery and methods. Pers Med. 2018;15:311-8.

16. European Commission. Europeans and biotechnology in 2010. Winds of change? 2010. http://ec.europa.eu/public_opinion/a rchives/ebs/ebs_341_winds_en.pdf. Accessed 02 Oct 2019.

17. European Commission. Special Eurobarometer 431-"Data protection"; 2015. https://ec.europa.eu/commfrontoffice/publicopinion/a rchives/ebs/ebs_431_en.pdf. Accessed 02 Oct 2019.

18. Hornung G, Schnabel C. Data protection in Germany I: the population census decision and the right to informational selfdetermination. Comput Law Secur Rev. 2009;1:84-8.

19. German Federal Constitutional Court, Judgement of the First Senate of 15 Dezember 1983 - 1 BvR 209/83 -, Rn. (1-215). http://www. bverfg.de/e/rs19831215_1bvr020983.html. Accessed 2020-03-29.

20. Vezyridis P, Timmons $\bar{S}$. Resisting big data exploitations in public healthcare: free riding or distributive justice? Socio Health Illn. 2019;8:1585-99.

21. Vogel G. German law allows use of DNA to predict suspects' look. Science. 2018;6391:841-2. 